\title{
51. DATA REPORT: GEOCHRONOLOGY OF THE GLAUCONITIC GRAINS IN THE LOWER CRETACEOUS OF HOLE 762C ON THE EXMOUTH PLATEAU ${ }^{1}$
}

\author{
Gilles Serge Odin, ${ }^{2}$ Pierre-Yves Gillot,${ }^{3}$ and F. Baudin ${ }^{4}$
}

\begin{abstract}
Sedimentological and geochronological investigation of glauconitic grains in the lower part of Hole $762 \mathrm{C}$ was undertaken. The glaucony facies indicates a transgressive event with low sedimentation rate allowing glaucony to reach a slightly evolved stage. Green grains of the samples studied result from the evolution ("verdissement") of coprolites of silt and clay of mud eaters. In spite of possible rejuvenation because of the immature stage of the glauconitic minerals and probable inheritance from the initial substrate, the apparent age of $132 \mathrm{Ma}$ calculated from the isotopic results is close to the time of deposition in late Berriasian to early Valanginian time.
\end{abstract}

\section{INTRODUCTION}

During Leg 122, Hole $762 \mathrm{C}$ was drilled on the Exmouth Plateau off northwest Australia in the eastern Indian Ocean. Knowledge of the age of the basal formation from this hole is crucial to the understanding of the evolution of this starved passive margin. The biostratigraphic age given by preliminary shipboard work was not conclusive. The core is full of glaucony-rich layers (the facies name glaucony is used for green grains before mineralogical study, Odin and Matter, 1981). A sample was selected for radiometric dating and a series of other samples were observed for a preliminary sedimentological study in order to obtain a better documented interpretation of the analytical data.

\section{STRATIGRAPHICAL CONSTRAINTS}

Shipboard biostratigraphical studies on Hole $762 \mathrm{C}$ led to some doubt about the age of the sample in question $(122-762 \mathrm{C}$ $81 \mathrm{X}-\mathrm{CC})$. An early Valanginian age was inferred. Land-based re-examination of the section yielded an age of late Berriasian to earliest Valanginian (Brenner, this volume, chapter 31).

Some questions should first be discussed before application of the analytical process. Knowledge of the Early Cretaceous numerical time scale is less accurate than desirable at the present, resulting in a rather wide variety in age estimates for stage limits of this subsystem.

Following discussion of the radiometric ages available, Kennedy and Odin (1982) suggest an age of 122-130 Ma for the base of the Valanginian stage. Snelling (1985) recommends an age of about $128 \mathrm{Ma}$, which is also an estimate used by Haq et al. (1987). Ages $10 \mathrm{Ma}$ older are preferred by Palmer (1981), but we know of no published radiometric dates directly supporting that proposal. A revised synthesis has been proposed for the Jurassic (Odin, 1989). The dates available are

\footnotetext{
${ }^{1}$ von Rad, U., Haq, B. U., et al., 1992. Proc. ODP, Sci. Results, 122: College Station, TX (Ocean Drilling Program).

2 Géochronologie et Sédimentologie Océanique, Unité Associée CNRS Tectonique et Stratigraphie, Université Pierre et Marie Curie, 4 place Jussieu, 75252 Paris Cedex 05, France.

${ }^{3}$ Unité Géochronologie, CFR, CEA Saclay-CNRS Gif, 91190 Gif-surYvette, France.

${ }^{4}$ Stratigraphie, Unité Associée CNRS: Tectonique et Stratigraphie, Université Pierre et Marie Curie, 4 place Jussieu, 75252 Paris Cedex 05, France.
}

not much more numerous than those available in 1982 . They only allow the assignment of the basal Valanginian within the rather large interval of time between 125-135 Ma.

\section{GEOCHEMICAL STUDY}

Radiometric dating of glauconitic minerals necessitates a sedimentological study in order to constrain the interpretation of the isotopic results. In this context, it is useful to consider the environment at the time of genesis: (1) the possibility of an inheritance of radiogenic isotopes from the initial substrate of glauconitization, and (2) the possibility of reworking and a long break in sedimentation at the time when green grains were formed. Syndepositional and postdepositional conditions of sediments are also relevant: (1) the quality of the geochronometer concerning its isotope retention, and (2) the thermodynamic conditions of the sediment during its history.

\section{Genetic Uncertainties}

\section{Presence and Nature of the Green Grains}

In order to get an idea of the depositional conditions and relative quality of the glauconitic minerals present in the lower part of Hole $762 \mathrm{C}$, a series of washings were observed from Cores $122-762 \mathrm{C}-81 \mathrm{X}$ to $-91 \mathrm{X}$. Glaucony is rare in Cores 122-762C-85X and 122-762C-86X, common elsewhere, and abundant in Cores 122-762C-91X and 122-762C-81X. The presence of some pyrite in all cores indicates early diagenesis, shortly after deposition and in the presence of abundant organic matter in this part of the section. This implies that there was no very long break in sedimentation during glaucony genesis as is common for evolved green grains. A long break would have allowed the organic matter to be destroyed before burial.

The sediments from Hole $762 \mathrm{C}$ show green grains resulting from the "verdissement" (a process of clay mineral genesis changing the color toward green: the word is defined in Odin, $1988 \mathrm{~b}, \mathrm{p} .418$ ) of ellipsoidal 100 - to $300-\mu \mathrm{m}$ large coprolites. This kind of substrate and process has been described from the modern seafloor. Glauconitization of coprolites is a good criterion for tracing a rather rapid relative sea-level rise (Odin and Fullagar, 1988); the latter may be estimated to be about 50-100 m. Alternatively, coprolites could have been transported downslope after formation, if such a slope was present. 
A previous study (Odin and Dodson, 1982; Odin, 1988a) has shown that such material is able to trap a considerable proportion of radiogenic isotopes as long as the glauconitization process has not lead to evolved to highly evolved glaucony facies (with more than $7 \%$ potassium oxide, $\mathrm{K}_{2} \mathrm{O}$ ). These inherited isotopes come from the initial substrate of clay and silt (fine fraction). We therefore undertook a study of both the green grains and the clay and silt fraction of the sediment in order to estimate any inherited isotopes that may have been present at the time of burial.

\section{Mineralogy of the Green Grains and Fine Fraction}

Following washing, magnetic separation and fractionation, and ultrasonic cleaning, granulometrically selected grains were submitted to X-ray diffraction. The best crystallized material (which results from the highest degree of evolution) was obtained from Sample 122-762C-81X-CC. X-ray diffraction of randomly oriented powders identified slightly evolved material $\left(4 \%\right.$ to $\left.6 \% \mathrm{~K}_{2} \mathrm{O}\right)$.

Several fine fractions were also X-rayed using oriented slides. The finer particles are essentially composed of more than $90 \%$ smectite with small proportions of mica and chlorite. The latter two minerals are more abundant in the coarser fractions (about $20 \%$ of the whole fine fraction) and radiogenic isotopes may be related to these minerals.

\section{Historical Uncertainties}

Important factors for argon retention in glauconitic minerals are the closure of the geochronometer (the degree of closure is directly related to the potassium content) and the thermodynamic constraints which may enhance diffusion or provoke recrystallization during the later sediment history. Because the glauconitic minerals are slightly evolved in the present sample, their closure is not good and the geochronometer should be considered particularly sensitive to thermodynamic constraints.

We have tried to estimate the presence of possible heating events in the sediments during their history. Following the mineralogical study of the clay-size fraction, we studied the organic matter as a second criterion for such an estimate (a third possibility would have been to search for apatite and perform fission track dating).

The Rock-Eval pyrolysis (Espitalié et al. 1985; Espitalié, 1986 ) is able to rapidly provide information about organic carbon content and origin and maturation of the organic matter. The latter character is measured using the pyrolysis temperature (when the highest amount of hydrocarbon components are generated by the thermal alteration of the organic matter). This parameter is noted as the maximum temperature $\left(\mathrm{T}_{\max }\right)$ and is expressed in ${ }^{\circ} \mathrm{C}$. It is directly linked to the cracking kinetics of the organic matter. One generally observes an increase in the $\mathrm{T}_{\max }$ with the increase in the evolution of the organic matter. This is because the chemical links which are preserved in the most evolved organic components are those which break apart at increasing higher temperatures. The selected sample is representative of a series of analysis which gave reproducible results according to parameters of Espitalié (1986). Rock-Eval results are shown in Table 1.

The total organic carbon content shows an usually high value for clayey sediments. The origin of this organic matter is difficult to determine because it was partly altered during the $10^{4}$ to $10^{5}$ years of evolution of the green grains in contact with seawater, but from our experience, we suspect a woody-coaly origin. The degree of alteration is indicated by the low hydrogen index (HI), and the high S3 parameter which characterizes the presence of oxygenated components. In spite of
Table 1. Results of Rock-Eval pyrolysis analysis on a glauconitic sample from the base of Core 122-762C-81X.

\begin{tabular}{ccccccc}
\hline Total organic carbon & $\mathrm{S} 1$ & $\mathrm{~S} 2$ & $\mathrm{~S} 3$ & $\mathrm{~T}_{\max }\left({ }^{\circ} \mathrm{C}\right)$ & $\mathrm{HI}$ & $\mathrm{OI}$ \\
\hline $1.5 \%$ & 0.1 & 0.46 & 0.98 & 417 & 30 & 66 \\
\hline
\end{tabular}

Note: $\mathrm{HI}=$ hydrogen index; $\mathrm{OI}=$ oxygen index; and $\mathrm{S} 1$ (total volatiles), S2 (hydrocarbon compounds), and S3 (oxygenated compounds) are parameters calculated from the pyrolysis.

this alteration, the different pyrolyses undertaken showed similar results. In particular, the $\mathrm{T}_{\max }$ parameter shows a constant value of $417^{\circ} \mathrm{C}$. This temperature indicates that organic matter from the sample is still immature (i.e., the material has not undergone an appreciable heating). This implies that a temperature of $100^{\circ} \mathrm{C}$ has never been reached in that part of the section. A temperature as low as $60^{\circ} \mathrm{C}$ may be the maximum.

\section{RADIOMETRIC STUDY}

The "best" available green grains (i.e., the most evolved) were selected for analysis. The fine fraction (less than about $10 \mu \mathrm{m})$ was prepared from the same sample (122-762C-81X$\mathrm{CC}$ ) following disaggregation of the sediment, elimination of organic matter using hydrogen peroxide $\left(\mathrm{H}_{2} \mathrm{O}_{2}\right)$ for half an hour (this clearly removes the dark organic matter and the fine fraction becomes lighter grey), rinsing by centrifugation, and quick sedimentation in water to remove the coarse fraction. The smallest size fraction (clay fraction $<2 \mu \mathrm{m}$ ) was not selected in order to analyze the fine fraction that was most likely ingested by mud-eaters (probably worms) that makes coprolite. The fine fraction and selected green grains (G 711) were submitted to potassium analysis using two different techniques (Table 2) and argon isotopic analysis using the unspiked technique (Cassignol and Gillot, 1982). Calibration of the analytical process was controlled using Glauconite GL-O and LP-6 biotite as reference materials (Odin et al., 1982). Table 2 gives the results (obtained in Gif-sur-Yvette, France).

\section{DISCUSSION}

\section{Isotopic Inheritance}

In the Gulf of Guinea, Senegal, and other areas, modern sediments contain green grains of the glaucony facies that are in the process of evolution. Some of these modern grains are at the same stage of evolution (slightly evolved) as the Cretaceous green grains from the Exmouth Plateau. This radiometric study showed that, before burial, these slightly evolved grains retained $10 \%$ to $20 \%$ of the radiogenic isotopes present in the original fine fraction eaten by the coprolitemaking organisms (Odin and Fullagar, 1988). This proportion

Table 2. Analytical results of the K-Ar dating of green grains and fine fraction separated from the same Sample 122-762C-81X-CC.

\begin{tabular}{lcccc}
\hline \multicolumn{1}{c}{ Sample } & $\begin{array}{c}\mathrm{K} \\
(\%)^{\mathrm{a}}\end{array}$ & $\begin{array}{c}\mathrm{Ar}_{\mathrm{rad}} / \mathrm{Ar}_{\text {tot }} \\
(\%)\end{array}$ & $\begin{array}{c}\mathrm{Ar}_{\mathrm{rad}} \\
(\mathrm{nl} / \mathrm{g})\end{array}$ & $\begin{array}{c}\text { Apparent age } \\
(\mathrm{Ma} \pm 2 \sigma)^{\mathrm{B}}\end{array}$ \\
\hline G 711 & 4.26 & 82.6 & 22.64 & $131.8 \pm 2.6$ \\
G 711 & 4.26 & 83.3 & 22.69 & $132.1 \pm 2.6$ \\
Fine fraction & 3.57 & 92.2 & 52.09 & $341.0 \pm 6.8$
\end{tabular}

a The mean of two analytical results using flame photometry and isotope dilution; reproducibility better than $\pm 1 \%$; accuracy controlled with reference material "Glauconite GL-O".

b Ages calculated using decay constants recommended by IUGS Subcommision of Geochronology. 
may, therefore, be considered a maximum possible inheritance in the grains dated from the Exmouth Plateau. Because the fine fraction dated in the present study contains a high content of inherited argon corresponding to an age of $340 \mathrm{Ma}$ (today), there was a significant amount of radiogenic argon in the glauconitic geochronometer at the time before burial and in the initial stages of closure. We can estimate this maximum initial content considering the fact that, at the time of deposition (about $130 \mathrm{Ma}$ ), the fine fraction was $210 \mathrm{Ma}$ (i.e., $360-130 \mathrm{Ma})$. It contained a quantity of argon estimated to be $15 \%$ of this age for a $\mathrm{K}$ content of $3.6 \%$ (this corresponds to about $4.7 \pm 1.6$ nanoliter per gram, or $\mathrm{nl} / \mathrm{g}$ ). This means that the minimum age of the glaucony is $110 \pm 8 \mathrm{Ma}$ (or AlbianAptian).

However, our most recent study (Odin and Fullagar, 1988) indicates that early diagenesis, during initial burial, usually provokes a recrystallization process of the glauconitic minerals leading to more ordered minerals. This process may reasonably be regarded as a factor for decreasing a proportion of the original inheritance (but not all of it). In summary, in view of the genetic uncertainties, the present apparent age of the green grains $(132 \pm 2 \mathrm{Ma})$ of the Exmouth Plateau is a maximum age for their initial time of deposition. A minimum age of this glaucony is $115-120 \mathrm{Ma}$ with a large error bar.

\section{Isotopic Rejuvenation}

In the Exmouth Plateau, the dated green grains were submitted to lithostatic and hydrostatic pressures of $850 \mathrm{~m}$ of sediment and $1360 \mathrm{~m}$ of water (equivalent to a total of $1350 \mathrm{~m}$ of rock). This is not an ideal situation for argon retention in a glauconitic mineral which is rather poor in potassium. However, the clay mineralogy (presence of dominant smectite) indicates that the sediments have not been submitted to sizeable burial diagenesis; moreover, the Rock-Eval pyrolysis indicates that the glauconitic sediments were not submitted to hydrothermal alteration and that thermal conditions remained very moderate during the whole history of the sediment.

\section{CONCLUSIONS}

From the sedimentological point of view the green grains from the Early Cretaceous of the Exmouth Plateau indicate that the coprolites formed at shallow depths $(5-20 \mathrm{~m})$. Following what can be considered a rapid (relative) sea-level rise, these coprolites were the substrates for in-situ glauconitization. The slightly evolved glaucony facies obtained indicates that the substrates were in close contact with seawater for no more than $10^{4}-10^{5}$ years. This process, and the nature of the substrate, allow the recognition of a transgression followed by a rather slow sedimentation rate during a limited interval of time.

The apparent age given by the dated glaucony is $132 \mathrm{Ma}$. This age most likely corresponds to an age older than the time of deposition due to the suspected inheritance of radiogenic isotopes from the initial substrate (inherited clay with $3.6 \% \mathrm{~K}$ and an apparent age of $341 \mathrm{Ma}$ ).

The thermodynamic conditions of the area were relatively quiet during the proceeding history as indicated by the abundant presence of smectite in the clay fraction and by the absence of maturation of the organic matter which points to a maximum temperature lower than $100^{\circ} \mathrm{C}$, and probably lower than $60^{\circ} \mathrm{C}$ during the last $130 \mathrm{Ma}$. These conditions are favorable for the preservation of the isotopic equilibrium in the green grains because no recrystallization is likely to have occurred. On the other hand, the low content of potassium in the glauconitic minerals is not a good criterion for preservation of the isotopic equilibrium; it is possible that argon diffusion occurred leading to some "compensation" of the inherited age, although no equality between these two processes can be imagined.

In this context, and considering the most recent development of the time scale calibration, the radiometric results indicate that the original glaucony genesis may have occurred during the Valanginian. A Hauterivian age appears less probable, but a late Berriasian age cannot be excluded.

\section{ACKNOWLEDGMENTS}

The study was achieved following suggestion by B. Haq, who is thanked deeply for collection of the dated sample and for the final manuscript improvements. R. Damotte and B. Galbrun helped by providing samples for the sedimentological and organic matter study. The French CNRS insured financial support for this research. W. B. Harris is thanked for suggesting improvements to a previous version.

\section{REFERENCES}

Cassignol, C., and Gillot, P.-Y., 1982. Range and effectiveness of unspiked potassium-argon dating: experimental groundwork and application. In Odin, G. S. (Ed.), Numerical Dating in Stratigraphy: Chichester (Wiley), 159-179.

Espitalié, J., 1986. Use of $T_{\max }$ as a maturation index for different types of organic matter: comparison with vitrinite reflectance. In Burrus, J. (Ed.), Thermal Modelling in Sedimentary Basins: Paris (Technip), 475-496.

Espitalié, J., Deroo, G., and Marquis, F., 1985. La pyrolyse RockEval et ses applications. Rev. Inst. Fr. Pet., 40:755-784.

Haq, B. U., Hardenbol, J., and Vail, P. R., 1987. Chronology of fluctuating sea levels since the Triassic. Science, 235:1156-1167.

Kennedy, W. J., and Odin, G. S., 1982. The Jurassic and Cretaceous time scale in 1981. In Odin, G. S. (Ed.), Numerical Dating in Stratigraphy: Chichester (Wiley), 557-592.

Odin, G. S., 1988a. Glaucony from the Gulf of Guinea. In Odin, G. S. (Ed.), Green Marine Clays: Devl. in Sedimentol. Ser., Amsterdam (Elsevier), 45:225-248.

(Ed.), 1988b. Green Marine Clays: Devl. in Sedimentol. Ser., Amsterdam (Elsevier), 45.

1989. The Jurassic time scale in 1988. In Odin, G. S. (Ed.), Calibration of the Phanerozoic Time Scale. Bull. Liais. Inform. IGCP Proj. 196 offset Paris, 7:38-49.

Odin, G. S., and Dodson, M. H., 1982. Zero isotopic age of glauconies. In Odin, G. S. (Ed.), Numerical Dating in Stratigraphy: Chichester (Wiley), 277-306.

Odin, G. S., et al., 1982. Interlaboratory standards for dating purposes. In Odin, G. S. (Ed.), Numerical Dating in Stratigraphy: Chichester (Wiley), 123-150.

Odin, G. S., and Fullagar, P. D., 1988. Geological significance of the glaucony facies. In Odin, G. S. (Ed.), Green Marine Clays: Devl. in Sedimentol. Ser., Amsterdam (Elsevier), 45:295-332.

Odin, G. S., and Matter, A., 1981. De glauconiarum origine. Sedimentology, 28:611-641.

Palmer, A. R., 1981. A geologic time scale. Geology, 11:503-504.

Snelling, N. J., 1985. An interim time scale. In Snelling, N. J. (Ed.), The Chronology of the Geological Record: Oxford (Blackwell), 261-265.

Date of initial receipt: 11 July 1990

Date of acceptance: 19 October 1990

Ms 122B-193 